ダム建設の是非を問うときに、周囲の自然環境、とりわけ生 態系に及ぼす悪影響が必ず話題に上ります。ダムの貯水・放流 によって、河川の水量や水流、水質などが变わることで、そこ に生息する動植物は直接の影響を免れません。

今月は、ダム建設によって、オーストラリアハイギョ
(Australian lungfish) が絶滅の危機に瀕しているという記事を 取り上げます。ハイギョは「生きた化石 (living fossil)」とよば れ、シーラカンスとともに陸上沗椎動物の祖先として位置づけら れる、進化を研究するうえで重要な生物です。解説を参考にしな がら、ハイギョをめぐる論争について、英語で読んでみましょう。

NEWS 語数 : 613 words 分野: 環境·生態·進化

Nature 442, 232-233 | doi: 10.1038/442232b; Published online 19 J uly 2006

\title{
Dam project threatens living fossil
}

http://www. nature.com/nature/journal/v442/n7100/full/442232b.html

Helen Pearson

Lungfish face extinction, say environmentalists.

1. We are about to lose a key piece of our evolutionary history, warn biologists. They are campaigning to save the Australian lungfish, which they fear could be sent extinct by an enormous dam planned for southeastern Queensland.

2. The hefty, muddy-brown fish (Neoceratodus forsteri) is thought to have survived virtually unchanged for at least 100 million years, making it one of the oldest known vertebrate species around and earning it the moniker of 'living fossil'. It is also one of the closest living relatives of the ancestral fish that crawled on to land and eventually gave rise to all land vertebrates, including humans. Being able to study the species is important for understanding how that transition took place.

3. The lungfish is now largely confined to two river systems in Queensland - among the only places that provide the shallow, running and weedy water in which the fish likes to spawn. A dam in one of these, the Burnett river, was completed last year in order to supply water to the droughtstricken region. The area has the fastest growing population in the country, and delivering water to the inhabitants is likely to be a huge problem in the future. But lungfish researchers say that by flooding or drying them out, the dam will eventually destroy nearly half of the lungfish spawning areas.
4. On 5 July, Queensland Premier Peter Beattie announced a decision to dam the second river, the Mary. Partly because the Australian lungfish is listed as a threatened species, the dam must pass a federal environmental-impact assessment before the project can proceed. But lungfish supporters believe the second dam could be enough to drive the species to extinction.

5. The latest decision prompted lungfish expert J ean J oss at Macquarie University in Sydney to step up a campaign to block the dam and persuade the federal government to intervene.

6. Joss has asked colleagues to e-mail Beattie and federal environment minister Ian Campbell to tell them about the scientific importance of the fish - so far more than 100 scientists have responded to her call. "It would be a calamitous and irreplaceable loss if this animal went extinct," says Per Ahlberg of Uppsala University, Sweden, who collaborates with J oss and is helping with the campaign.

7. There are five other species of lungfish living in South America and Africa. But the Australian lungfish, which can live for a century and grow 1.5 metres long, is thought to most closely resemble the last common ancestor of land vertebrates. 
8. Biologists say that living fish can be used for genetic and embryology studies that probe how vertebrates moved from water to land - analyses that would be impossible with preserved specimens. Joss and Ahlberg, for example, are studying the lungfish's patterns of gene activity, to try to work out how fins became limbs. "These things are amazingly important organisms in the history of the Earth, " says William Bemis who studies vertebrate evolution at the University of Massachusetts, Amherst.

9. The Queensland government has guaranteed that the dam will include a 'fish elevator' to carry lungfish across the dam and says that it will do whatever it takes to meet federal environmental requirements, as it did with the last dam. But Joss says that this is not enough, because the lungfish's old spawning grounds will still be destroyed. Lungfish lay very few eggs, and return to the same spawning sites year after year.

10. Should the campaign fail, Joss says she will petition Beattie for money to set up a lungfish breeding centre. But guaranteeing the species' survival in captivity would be tough. So far J oss is the only researcher who has managed to breed them, using two ponds, each the size of an Olympic swimming pool.
著作権等の理由により画像を掲載することができません。

ヒトの遠い祖先オーストラリテ ハイギョは生き残れるだろうか

Science key words

2. vertebrate :「沗椎動物」

$\Leftrightarrow$ invertebrate「無脊椎動物」

3. spawn : 「放卵する」

動物の産卵のうち、特に水生動物が周辺に卵を散布する 形式の産卵。spawning area やspawning site は「産 卵場」のこと。

4. threatened species : 「絶滅の恐れのある種、絶滅危惧種」 国際自然保護連合(IUCN)のレッドリストによる分類区分で、 critically endangered (絶滅危惧 IA 類), endangered (絶 滅色惧 IB 類)、vulnerable (絶滅危惧 $I$ 類) という3 つの 下位区分がある。2006 年には 16,119 種が認定されてお り、ホッキョクグマやカバなども含まれる (http://www. iucnredlist.org/参照)。

7. last common ancestor: $\ulcorner$ 最終共通祖先」 ここでは、特定の 2 種以上の生物について進化の過程を 遡っていったときに交わる祖先のうち、いちばん最近の ものを表している。

9. 'fish elevator' : 「(エレベーター方式の) 魚道」 魚道は一般に fish passや fish-way などとよばれ、ダム や堰などで魚が遡行できない箇所で、遡行を助けるために 設けられた設備のこと。エレベーター方式のほかに階段方 式など、さまざまな種類があるが、魚類以外のほとんどの 生物には助けとならないことが多い。

\section{Words and phrases}

タイトル living fossil : 「生きた化石」

living〜は論文によく出てくる表現で、living animal、 living cell, living tissue などのように使われ、生きた〜」「生 〜」「生体〜」と訳される。living fossil は比ゆ的な表現。

1. sent extinct : send extinct の受動形で、絶滅させられる」。 「絶滅」に関連した表現としては、ほかにも第 4 段落にdrive 〜 to extinction「〜を絶滅させてしまう」、第 6 段落にgo extinct「絶滅してしまう」の過去形が出ている。

2. hefty : : heft「重量」「重いこと」が形容詞になった語。もと もとは「重い」という意味だったが、のちに「サイズが大きい」 「金額が大きい」という意味が加わった。

2. moniker :「名前、あだ名」

3. confined to .... :「〜に限定される」「〜の範囲内に限られる」 3. weedy : weedには「雑草」のほかに、「水草」「海藻」の意 味もある。この文章は川の話なので、水草がたくさん生えてい ることを意味する。
3. drought-stricken region : 「干ばつ地帯」

drought-stricken は-stricken「〜に見舞われる」「〜に襲わ れる」を使った複合語。drought は「干ばつ」「日照り」のこと。

5. intervene: 「介入する」

6. calamitous:「悲惨な、痛ましい」「災難の多い」 名詞の calamity「大災害、災難」「不幸」から派生した形容詞。 calamity に満ちた状態、あるいは calamity を引き起こすよ うな状態のことを意味する。

9. do whatever it takes to ... : 「〜するために必要なことは 何でもする」

It takes A to 〜 「〜するためにはA が必要」という表現が変形 したもの。

10. in captivity : 「捕らえられて」という意味だが、科学記事で は「野生の生物を捕まえてきて飼育すること」「研究室や動物 園で生まれた生物を飼育する」という意味にもなる。 
Nature 442, 232-233 | doi: 10.1038/442232b; Published online 19 J uly 2006

\section{ダム建設プロジェクトで「生きた化石」が窮地に}

http://www.nature.com/nature/journal/v442/n7100/full/442232b.html

ヘレン・ピアソン

ハイギョ (肺魚) が絶滅の危機に瀕していると環境保護論者はいう。

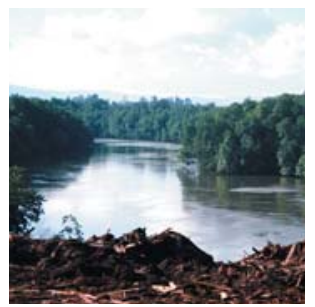

1.人類の進化の歴史にとって極めて重要な手がかりが失わ れようとしている、と生物学者が警告している。彼らが運 動を通じて守ろうとしているのはオーストラリアハイギョ で、クインズランド州南東部に建設が計画されている巨大 ダムによって絶滅してしまうことを心配しているのだ。

2. 濁った茶色の大型魚であるオーストラリアハイギョ (Neoceratodus forsteri) は、少なくとも 1 億年の間、ほ ぼ昔のままの姿で生き続けてきたと考えられている。現 生脊椎動物種の中では最古の部類に入ることが知られて おり、「生きた化石」とよばれている。また、陸上に這い 上がり、最終的にはヒトなどの陸上脊椎動物に進化して いった魚類の祖先種と最も近緑な現生種の 1 つでもある。 この進化上の移行過程を解明するうえで、オーストラリ アハイギョの研究は重要となっている。

3. 現在、オーストラリアハイギョの生息地は、クインズラ ンド州の 2 つ水系にほぼ限定され、特に産卵場として 好まれる、浅くてよどみがない、水草の生い茂った場所 に限られている。そのような水系の 1 つであるバーネッ ト川では、干ばつ地帯へ水を供給するためのダムが昨年 完成した。この川の流域は、国内でも人口増加率が最も 高く、住民に対する水の供給は将来的に大問題となる可 能性が高い。これに対してハイギョの研究者は、ダムが そのうちにハイギョの産卵場を汇濫させ、あるいは干上 がらせて、その半数近くを破壊してしまうという。

4. 7 月 5 日、クインズランド州首相 Peter Beattie は、も う 1 つの水系であるメリー川にもダムを建設することを 発表した。オーストラリアハイギョが絶滅危惧種に指定 されていることもあり、このダム建設プロジェクトを進 めるには、連邦政府の環境影響評価に合格する必要があ る。しかしオーストラリアハイギョ保護運動に賛同する 人々は、この第 2 のダムでオーストラリアハイギョは十 分に絶滅する可能性があると考えている。

5. ダム建設の決定を受けて、ハイギョの専門家であるマッ コーリー大学（オーストラリア、シドニー）の Jean Joss は、ダム建設を阻止し、連邦政府の介入を働きかける運 動を強化した。
6. Joss は、研究者仲間に対し、Beattie 首相や連邦政府の 環境大臣 Ian Campbell に電子メールを送り、オースト ラリアハイギョの科学的重要性を伝えることを依頼した。 これまでのところ、100人を超える科学者が彼女の要請 に応えている。「オーストラリアハイギョの絶滅は、悲惨 で取り返しのつかない損失となるでしょう」。こう語るの は、JOSS と共同研究を行い、この運動を手伝っているウ プサラ大学（スウェーデン）のPerAhlberg だ。

7.このほかにも 5 種類のハイギョが南米とアフリカに生息 しているが、最長寿命が 100 年で、体長が 1.5 メートル にもなるオーストラリアハイギョは、陸上脊椎動物の最 終共通祖先に最もよく似ていると考えられている。

8. 生きた魚は、脊椎動物が水中から陸上に移動した過程を 調べるための遺伝学研究や発生学研究に使えるが、この ような解析研究を保存標本で行うことは不可能だ、と生 物学者はいう。例えばJoss と Ahlberg は、オーストラ リアハイギョの遺伝子活性パターンを研究し、ひれが手 足に変わった過程を解明しようと試みている。「地球の歴 史上、ハイギョは極めて重要なのです」。こう話すのは、 マサチューセッツ大学（米国アマースト）で沗椎動物の 進化を研究するWilliam Bemis だ。

9. クインズランド州政府は、オーストラリアハイギョをダム の反対側まで運ぶ「魚のエレベーター」を設置することを 保証し、前回のバーネット川でのダム建設と同じように、 連邦政府の環境要求事項を満たすために必要なことは全部 行うと発表している。これに対してJossは、昔からある ハイギョの産卵場が破壊されることに変わりはないので、 これでは不十分だという。ハイギョは産卵数が非常に少な く、毎年同じ産卵場に戻ってくる習性があるのだ。

10. 現在の運動がうまくいかない場合には、オーストラリア ハイギョの繁殖施設を建設するため資金拠出を Beattie 首相に陳情する、とJoss はいう。しかし飼育された状態 でハイギョの生き残りを保証するのはむずかしいと思わ れる。これまでのところハイギョの繁殖に成功している 研究者はJOSS だけで、オリンピック競技用プールと同じ 大きさの 2 つの池を使っている。 